\title{
Desecuritisation as a soft power strategy: the Belt and Road Initiative, European fragmentation and China's normative influence in Central-Eastern Europe
}

\section{Małgorzata Jakimów ${ }^{1}$ (D)}

Published online: 13 September 2019

(C) The Author(s) 2019

\begin{abstract}
While much discussion centres on economic properties and political challenges of implementing the China's Belt and Road Initiative (BRI), few studies investigate the subtle connections between the narratives of the BRI and the political transformations in the regions en route of the project. Through a critique of the Copenhagen School's theory of securitisation, this paper brings together the analysis of Chinese, CentralEastern European (CEE) and the core EU governments' ideas and perceptions of the BRI and assesses what they mean for the future of the European Union's political and normative cohesion. This paper argues that the China-deployed desecuritised narratives of the BRI constitute an important soft power strategy of China in its engagement in Europe. The article illustrates how these desecuritised narratives are utilised and coproduced actively by countries of CEE with a political aim of negotiating their domestic interests with the EU's institutions, making the process of desecuritisation neither apolitical nor benign. As China-promoted desecuritisation is used instrumentally by the regional actors to present China as an economic, political and normative alternative to the EU, the article contributes to the understanding of China's desecuritisation as a soft power strategy, which is both forged through 'negative' language (Callahan, Politics 35(3-4):216-229, 2015) and is 'contingent' upon recipient audiences (Kavalski, Coop Confl 48(2):247-267, 2013). As a result, new regional dynamics emerge in the EU, which are driven by the populist turn and growing demand for Chinese investments in the European periphery, which China skilfully utilises through narratives of desecuritisation in order to boost its soft power strategy in the region.
\end{abstract}

Keywords Belt and Road · 16+1 · European Union · Desecuritisation · Soft power · Normative influence

Małgorzata Jakimów

m.j.jakimow@durham.ac.uk

1 School of Government and International Affairs, University of Durham, Durham, UK 
In August 2017, the former German foreign affairs minister, Sigmar Gabriel, commented on the Chinese involvement in Central-Eastern Europe (CEE) as violating the principle of 'one Europe': 'If we do not succeed (...) in developing a single strategy towards China, then China will succeed in dividing Europe' (Gabriel quoted in Poggetti 2017). This remark comes at the time of a growing division on the European continent as to how the European Union (EU) should respond to the flow of China's investments through the Belt and Road Initiative (BRI), particularly in the light of the China's 'Made in China 2025' plan (EUCC 2017). The split seems to run between the so-called core European states, especially France and Germany, who, alongside the EU institutions, are increasingly critical of China's engagement in Europe, and much of the so-called European periphery, the countries of South, South-Eastern (SEE) and Central-Eastern Europe, who see the engagement as 'reviving' their economies. Among this European 'periphery', the 16+1 regional platform awakens the greatest controversy in Western European capitals (Kynge and Peel 2017). The 16+1 platform was created by China in 2012 mainly as a mechanism to facilitate the BRI implementation in the $16 \mathrm{CEE}$ and SEE post-communist countries, 11 of which are EU member states and 5 of which are in some stage of the EU accession process. ${ }^{1}$ The initiative has been perceived in security terms since its inception: China has been accused of a divisive 'checkbook' diplomacy (Le Corre 2016), and portrayed as undertaking 'authoritarian advance' by spreading its illiberal model in the region (Benner et al. 2018). The European Parliament Strategic Centre directly frames initiatives such as $16+1$ as having 'potential to split the EU', because of China's 'parallel negotiations with regions, cities, private companies, EU institutions, member states and geographical groupings' (EPSC 2016: p. 8). The German press in particular has been critical of the project's geopolitical threat and its potential to erode European political unity due to the competition for Chinese investments (Gaspers 2016). However, while Western European countries and EU institutions see this engagement in security terms, the CEE states view it as a benign force bringing with it economic investments without political strings attached. This contrasting response to China's presence in CEE — one of the securitisation in the European core and the simultaneous desecuritisation in its periphery-is the point of departure for this article.

In this article, I argue that desecuritisation is a key strategy in China's soft power politics in the European region. I refer to the process of 'desecuritisation' rather than 'depoliticisation' of China because the narratives that convey it are clearly aimed at changing the pre-existing 'China threat' perceptions and render China a non-security issue. $^{2}$ By tracing how desecuritisation narratives are deployed, adopted and co-

\footnotetext{
${ }^{1}$ These are Albania, Bosnia and Herzegovina, Bulgaria, Croatia, Czech Republic, Estonia, Hungary, Latvia, Lithuania, Macedonia, Montenegro, Poland, Romania, Serbia, Slovenia and Slovakia. While 16+1 region comprises of both CEE and SEE states, it is jointly referred to as CEE in Chinese publications, and in this article, I will adopt this convention for brevity purposes. In this article, I focus on the discussion of the Visegrad group countries (V4) mostly in section three, but some of the findings, particularly those stemming from the Chinese publications in section two, can be extended more widely to the entire $16+1$ region

2 'China threat' theory refers to a belief that China is a threatening state because of the perception of it as a major contestant of the current US-dominated world order, and a normative challenger to the West-promoted norms of democracy and human rights. It has been particularly presented as such since the Tiananmen massacre, as China was perceived as the one of the few remaining Communist states. The 'China threat' debate has been central to the realist debate on China rise and US-China competition and often relied on theories such as 'power transition' or 'successive state image' theory (see Jeffery 2009). China-promoted desecuritisation narratives discussed in this article are working precisely against such perceptions.
} 
produced in the CEE, this article reveals that the success of China's soft power strategy, and the attending ideational or normative influence that soft power brings in the region, is conditioned by the CEE states own agency in approaching China's desecuritisation. While desecuritisation enables the adoption of some 'China promoted norms', ultimately, the regional governments adopt them flexibly and pragmatically, and in order to secure political power at home or to improve their negotiating position with the EU institutions. The article therefore explains that while in the context of EU-China relations desecuritisation is indeed China's key soft power strategy, it is largely shaped by a specific dynamic between Europe's core and peripheral states, whereby the CEE states have more agency that it is usually portrayed. ${ }^{3}$

In order to understand the effectiveness and mechanism of desecuritisation, it needs to be properly contextualised within the particular regional dynamic. The case study of the CEE region is instructive in this respect as it shows that while China-projected ideas of the self are important, the receptiveness of the actors with whom China engages is crucial in the process of successfully deploying soft power through desecuritisation. Indeed, the desecuritisation process, just like its reverse, is produced intersubjectively, that is, it can only happen if the 'audience accepts it as such' (Buzan et al. 1998: p. 25). In the case of CEE, its contrasting response towards China, compared with that of the 'core' EU countries, needs to be contextualised within the historical East/West divide. The China-deployed desecuritisation engages with these dynamics and co-produces them. It is important to differentiate here between different parts of the $16+1$ region. The political elites from the EU member states in the region, and particularly the Visegrad group countries (V4: Czech Republic, Hungary, Poland and Slovakia), tend to view the China-promoted desecuritised narratives and institutions of the BRI as useful tools in countering what they perceive to be Brussels' incursion into their sovereignty. Here, the adoption of China's desecuritisation narratives should therefore be understood within the wider rise of populism and nationalism, accompanied by the rhetoric of emancipation from the EU's political conditionality (or the so-called Brussels consensus). On the other hand, Balkan non-EU states tend to use the China's influence to negotiate faster integration into the EU and to demand greater EU assistance to the region (ex. Djukanovic quoted in Zuvela 2019). Therefore, desecuritisation is 'contingent' (Kavalski 2013), that is, it relies on co-production rather than on simple export of ideas.

Because of their obscure and interpretative nature, the desecuritisation narratives cannot be easily measured and need to be traced in speech acts and through interpretation of actions of particular political agents. This article traces narratives, behaviours and institutions, as they are formulated, expressed and enacted in government documents, official pronouncements and communiques in both the CEE states and in China. In order to trace the power relations and intentions underlying these texts, I used qualitative methods of contextualised text analysis best associated with the critical discourse analysis approach, whereby the texts are analysed in-depth and with attention paid to the particular vocabulary used and the way in which this vocabulary masks or

\footnotetext{
3 The CEE states are often presented to be manipulated and controlled by more powerful states and political agents, lacking own will or agency. As the discussion in this article reveals, the Chinese authors perceived the CEE to be controlled by the EU and US (ex. Liu 2014; Long 2014), whereas the Western pundits largely perceive the CEE as blindly falling into the China-set honey traps of investments, apparently blind to the political string attached (ex. Hala 2018).
} 
conveys the power relations and political agendas in the contexts studied. I surveyed the main government speeches of high Chinese officials which related to the BRI deployment, particularly the main documents regarding the BRI produced by the Chinese government as well as speeches given by Xi Jinping and Li Keqiang in international fora. I also sought to identify the main speeches given by CEE politicians, but here, the selection was limited to only those speeches which were translated to English or available on internet. I identified several speeches in original regional languages (Polish, Czech and Serbian) but relied mostly on available translations when it comes to remaining countries in the region. A future in-depth study comparing speeches and official documents released by the regional governments could further complement this article's findings. Moreover, due to the space constraints, this article does not include the study of the media, the people-to-people, businesses and academic engagement with China in the CEE. The non-state actors' views are diverse and differ with regard to the treatment of China as 'security threat', with some perceiving China as a security threat while others not (Pavlićević 2018). While these views are important, studying the governmental approach is of utmost urgency because it translates directly into policy-making. However, while this article does not survey these wider epistemic communities, it does include the analysis of think tank and academic narratives in China. In the case of China, this level of analysis is more closely tied to the government, and the scholarly interpretations of the major official slogans and directives can help to analyse the governmental intentions and policies. This is so, because the slogans employed in the official speeches are often vague and require further interpretation, and it is the Chinese academics' role to 'look for patterns in order to add meaning to vague official declarations' (Callahan 2016: p. 228), contributing to China's policy-making.

The first section of the article contextualises it within the relevant theoretical literature on desecuritisation and soft power in China. The second section provides the discursive analysis of the Chinese sources, and reveals how the desecuritisation narratives are deployed and why they should be regarded as central instrument in China's BRI soft power strategy. At the same time, this section highlights the inherent contradictions within these narratives. In the third section, the article discusses the reception of the desecuritised portrayal of the BRI in CEE in order to show how the language of BRI is used by the countries in the region, elaborating on the co-produced nature of the Chinese soft power. In the concluding part, the article investigates the consequences of the adoption of the desecuritised narratives in CEE for the European normative cohesion, revealing the role of desecuritisation as a political instrument deepening EU fragmentation alongside the old and new regional fractures.

\section{Desecuritisation as a soft power strategy}

The link between desecuritisation and soft power merits wider theoretical investigation. Currently, in critical security studies (CSS), there is little attention paid to how desecuritisation serves political agenda of states, and even less so, how it can serve as a tool of soft power politics. While the Copenhagen School's (CS) theory of securitisation concerns itself primarily with the political consequences of 'securitisation', which it treats as a 'negative' process (Buzan et al. 1998: p. 29), the 'desecuritisation' process is less carefully researched and automatically assumed to be 
'positive' (Cui and Li 2011). Securitisation produces a perception of an issue as an 'existential threat, requiring emergency measures', being a 'more extreme version of politicisation', because it frames 'the issue either as special kind of politics or as above politics' (Buzan et al. 1998: pp. 23-24). In contrast, desecuritisation is desired, because it returns the objects to 'the ordinary public sphere' process (Buzan et al. 1998: pp. 4, 29). However, this approach has been critiqued in CSS on the ground that it forgoes the political and normative implications of desecuritisation (Hansen 2012: pp. 527-528; Aradau 2004; Floyd 2015). Floyd noted that securitisation and desecuritisation can be both just and unjust, and neither should be seen as morally more favourable (Floyd 2015: p. 122). This article is concerned precisely with such political and normative consequences of desecuritisation. By tracing the way in which desecuritisation is deployed by China and then adopted in CEE, this article shows how desecuritisation is a political act of deploying soft power precisely because it makes political intentions and processes appear as 'natural' and 'neutral', normalising China's actions with the aim of convincing international audience of China's benevolence.

In order to explore how desecuritisation becomes a soft power strategy it is important to consider the issues of agency and intentionality behind both desecuritisation and soft power deployment. An important aspect of this process is the extent to which the securitising agent as well as the target audience of the action play part in the success of desecuritisation. Much of the literature sees China as undertaking various forms of desecuritisation as a response to securitisation moves, particularly by the US and its Asian neighbours (Biba 2014; Vuori 2018: pp. 127-128; Danner 2014); but the importance of pre-emptive desecuritisation has also been mentioned (Weaver 1995: p. 60; Bourbeau and Vuori 2015). Apart from desecuritisation, the reverse securitisation, that is a securitisation of the securitising actor back (Vuori 2018: p. 120), as well as counter-securitisation, that is resistance to securitisation (Topgyal 2016; Vuori 2011), can be answers to the securitisation moves. Most importantly, some argue that successful desecuritisation is only possible by nontalking (lack of speech acts), rather than presenting oneself as non-threatening in response to securitisation (Behnke 2006: p. 65). Indeed, it has been noted that China uses the strategy of non-securitisation, as a pre-emptive form of desecuritisation in relations with its neighbours in the Mekong River Delta (Biba 2014: p. 35). This paper presents a case study of desecuritisation as an active response to securitisation, rather than a pre-emptive move, and it builds on this literature by paying special attention to the role of the audience.

None of the above-mentioned literature directly discusses the role of securitisation or desecuritisation as the primary tool of soft power or the role of the audience in the shaping of desecuritisation. The concept of 'soft power' was originally employed to discuss how the state can exert power through language, culture and economy by attracting (rather than coercing via military means) others to the state's own ideas and visions (Nye 1990: p. 166). ${ }^{4}$ The way in which soft power is deployed by China via

\footnotetext{
${ }^{4}$ The concept of soft power has been contested and increasingly replaced by new ways of describing China's normative influence, such as normative power (Kavalski 2013; Pu 2012; Kerr 2015), sharp power (Walker and Ludwig 2017) and symbolic power (Vangeli 2018). The deeper engagement with these new approaches lies beyond the parameters of this paper. In this article, I primarily engage with the concept of soft power in the discussion of how China shapes others' preferences, because it is less-value laden than the notion of sharp power, and less determined to be about norms-transfer than the notion of normative or symbolic power.
} 
language of desecuritisation is mentioned in some more recent works on soft power, taking identity and audience of the soft power discourses into account. Callahan, for instance, argues that soft power relies greatly on boundary-making between Self and Other (Callahan 2015: p. 219), meaning that China emphasises its 'difference' as the very strategy of soft power, targeting the recipient audiences' identity and interests. For instance, China emphasises the civility of its peaceful rise as opposed to the past bloody colonial conquests of the Western states when dealing with African or South-East Asian countries. This emphasising of China's difference is a way to exert 'soft power', a strategy which Callahan calls 'negative soft power' (Callahan 2015). Such 'negative soft power' is employed in China's promotion of the BRI, which combines the claims of China's benevolence (compared with the West) and its non-interference in domestic affairs (compared with the Washington consensus conditionality) (Breslin 2011; Vangeli 2018). 'Negative soft power' is therefore built through the language of desecuritisation. Yet, this power would only be effective if the recipients buy into the desecuritised narratives. When discussing the effectiveness of China' soft power, the importance of the recipients' context, which Kavalski dubs 'contingency' (Kavalski 2013), has to be further investigated. There are limited studies on how China's desecuritisation is shaped by the receipting audiences. Biba (2014), for instance, portrays desecuritisation as a very much China-controlled process, whereby China's self-portrayal as a co-operative and good-willed actor is often met with resigned acceptance (Biba 2014: p. 36). The rest of this article explores whether the agency of the recipient audience of desecuritisation matters in its success, and whether it can indeed co-produce or resist desecuritisation.

\section{China's desecuritisation narratives and their contradictions}

The way in which the soft power strategy of desecuritisation is exerted in practice can be traced in China's narrative on the BRI. In these narratives, desecuritisation is achieved through what is not uttered, rather than what is actually said. In Xi Jinping's various addresses promoting the BRI, he emphasises economy, culture and noninterference as key aspects of the BRI, redirecting attention from norms, politics, and international dependencies (respectively) which are often seen as true consequences of China's 'go global' policy, and the basis of the growing European perceptions of 'China threat' (see ex. Godement et al. 2011; Benner et al. 2018). In the 2015 Boao speech, for instance, Xi emphasised the importance of mutual respect for South East Asian countries' 'social system and development paths of their own choice' (Xi 2015), emphasising national sovereignty, not the potential consequences of China's influence in the region. Similarly, in the crucial BRI document 'Vision and Actions on Jointly Building Silk Road Economic Belt and 21-st Century Maritime Silk Road' (NDRC 2015) any reference to the BRI as a geopolitical project is omitted, and, as with other documents, the BRI is portrayed in a depoliticised language of economic development and cultural exchanges. A similar way of talking about the BRI was re-emphasised at the 2017 Beijing BRI Forum speech, where Xi highlighted the economic investments and cultural exchanges as the core of the BRI projects: these are to bring 'peace and cooperation', 'openness and inclusiveness', 'mutual learning' and 'mutual benefit' and foster 'a new type of international relations featuring win-win cooperation' (Xi 2017). 
Implicitly by 'new' $\mathrm{Xi}$ means here 'less aggressive' than the former Western forms of globalisation. Here, desecuritisation is achieved by presenting China's engagement as focused on economic projects or cultural exchanges, and adhering to the principle of non-interference, clearly contrasting it with the political or normative influence characterising 'Western' globalisation project.

In the context of Chinese investments in Europe, China has effectively created a narrative of China as 'rescuer' and its investments as 'reviving' Europe: a narrative that since the Greek debt crisis and the south European austerity programmes are gaining traction in the EU's periphery (Zhang and Trigkas 2015; Shi 2014). In this context, the BRI has similarly been portrayed in a desecuritised, Europe-friendly way: as helping to revive Europe economically and preserve its unity because the economic investments can ease internal tensions between the EU's core and periphery (MOFA 2015). Chinese leaders have long and vocally supported EU's unity, stability and prosperity, a commitment recently re-emphasised by the Chinese Foreign Affairs Minister Wang Yi (Xinhua 2017). The view that Europe's collapse or the rise of populism and nationalism are detrimental to China's interests is also shared by Chinese academics and pundits (ex. Liu and Chen 2017).

The Chinese official government-level approach towards the particular grouping of 16 CEE countries builds on these desecuritised narratives of the BRI. In his 2017 16+1 summit speech, the Chinese premier Li Keqiang emphasised the place of $16+1$ platform not as a competition undermining the EU institutions, but rather as a 'stability response' to the 'uncertainty of international situation' and 'an important component and beneficial complement to the China-Europe relations' (Li 2017). This language is clearly aimed at addressing the growing securitisation of $16+1$ among the core European states. Similarly, president Xi Jinping has now made it a tradition to produce op-eds directed at a wider public prior to his official visits to the CEE countries. In these op-eds, $\mathrm{Xi}$ emphasises the close cultural exchanges and admiration for national developments and heroic achievements of the CEE countries, buttressing nationalistic feelings (ex. Xi 2016). These op-eds and speeches, emphasising cultural and historic achievements and economic pragmatism as the foundation of mutual relations, are clearly aimed at creating a friendly and benign portrayal of China and its intentions, and desecuritising it in the eyes of the wider public and politicians alike by strengthening national sentiments and addressing the post-colonial insecurities of newly independent states.

Yet, while most academic and think tank publications from China tend to maintain a similar, desecuritised view of the BRI implementation in Europe, they expand on the meaning of many official statements and policies revealing inconsistencies in China's desecuritised vision of the BRI. Similarly to the official approach, they emphasise how China's engagement in CEE is improving EU-China relations and helping EU's unity (Jia 2013; Liu 2014; Long 2014). The engagement with the CEE regional institutionbuilding through the $16+1$ platform is presented not as a competition to the EU, but as a necessity, given the region's diversity and internal divisions (Xu 2013; Long 2016). However, at the same time, Chinese authors treat the CEE region as somehow separate from the EU: as a post-colonial space suspended between Russia and the EU, manipulated by Western media, and only recently 'Westernised' (Liu 2014; Long 2014). In this context, the core EU countries' reactions to China's engagement in CEE are seen as 'envious and alarmist' (caiji jingti) and dictated by their desire to control the region (Long 2014). A different choice of political and economic path of development to 
China after 1989 is also interpreted as a consequence of the Western hegemony, rather than a sovereign, domestic choice. ${ }^{5}$ This adoption of such Brussels' dictum led CEE countries to erroneously treat 'human rights as more important than sovereignty' (renquan gaoyu zhuquan) in their domestic politics and approach towards China (Long 2014). Finally, while the academic and think tank publications stick to the official line and treat China-CEE relations as economically-motivated and pragmatic (Xu 2013), they recognise them primarily as 'testing grounds' (shiyantian) for Chinese products and strategies before entering Western European markets (Liu 2014; Long 2016). This makes the CEE a crucial battlefield for improving China's image and building its soft power, as the successful implementation of the BRI projects can change the EU's 'over-sensitive and biased' (mingan he pianmian) perception of China (Xu 2013). This approach reveals the recognition of the importance of CEE in the deployment of China's soft power by exploitation of the EU's core-periphery differences, rather than by contributing to its unity.

The recognition of the region as a key target area for the deployment of China's soft power is particularly visible when the views on China's engagement in the region are compared over the period prior to and after 2015. After 2015, in the context of rising populism, refugee crisis and Brexit in Europe, seen as emblematic of a growing European fragmentation and re-nationalisation, the publications indicate a growing assertiveness of China via-a-vis Brussels in its dealings with the region, as well as a clearer normative drive behind the engagement. Following these developments, China's relationship with the region is undergoing 'an epic shift', based on the new China's 'two-legged policy' (liangtiaotui), which relies on increasing the bilateral relations with particular states, rather than continuing to deal with the $16+1$ region through the framework of EU-China relations (Liu and Golik 2016: p. 118). In this context, the EU is increasingly perceived as an unfriendly force: it is seen to be piling 'hidden obstacles' in a 'Cold War' fashion to regional cooperation with China, such as control of public debt and financial deficit of the CEE member states, preventing China from purchasing their debt bonds (Long 2016: p. 9). CEE once again is understood as a post-colonial space, but now, the academics praise the growing assertiveness of the countries such as Serbia or Poland towards Brussels. They note that these countries are increasing their engagement with non-EU countries, such as China, as a consequence of 'grabbing space for autonomy' from the EU (Long 2016: p. 9; Liu 2016). While these authors see European fragmentation as potentially detrimental to the BRI project in the EU, because it can lead to increased protectionism of domestic markets (Liu and Chen 2017: p. 30), China can turn this situation to its advantage: the political fragmentation and populist turmoil in Europe can create space for China to 'transmit its core values' (chuanbo Zhongguo kexinjiazhiguan), by 'realising China's way' (tixian Zhongguo daolu) and attracting countries by 'showcasing the superiority of the Chinese system' (Zhongguo zhidu youyuexing) as opposed to the 'bad West's' (Xifang bu liang) neoliberal values which in the era of populism have been turned 'upside down' (Liu and Chen 2017: p. 35). The way to counter the 'negative narratives on China' coming from the EU and US in the region is by creating think tanks and people-to-people exchanges in order to divert the public opinion in CEE into a more 'objective and just'

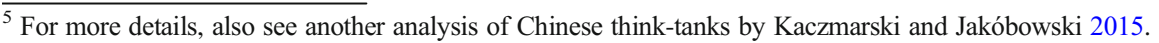


direction (keguan gongzhen de fangxiang) (Long 2016: p. 10): that of desecuritised China image.

The above Chinese perspectives of the region tell us much not only about the inconsistencies in the desecuritised portrayal of the BRI and the use of such image as a soft power tool, but also about how China engages with and co-produces regional dynamics for its own ends. While the official narratives desecuritise China's BRI presence in CEE by portraying it as Europe-friendly, and mainly centred on economic and cultural exchanges, the academic publications reveal that China's objectives behind its engagement with the region are deeply strategic, if not normative, and in order to meet these objectives China aims to increase its soft power in the region. This, as the analysis has shown, is best achieved through desecuritisation narratives. In its deployment of these narratives, China learns from the context of the countries which are to participate in the BRI, and adapts its strategies and language accordingly to that context. Here, China employs the negative soft power strategy achieved through counter-securitisation of Western Europe. This strategy invokes, what I call, a community of 'shared disenchantment' (rather than 'shared destiny'), which builds on decadeslong Third World alignment rhetoric of sharing in other countries postcolonial struggles (Van Ness 1995: p. 195; Kowalski 2017). In this rhetoric China portrays itself as a friend in a struggle against the common enemy encroaching on vulnerable countries' sovereignty. The language emphasising economy (rather than politics), culture (rather than norms), and sovereignty (rather than supranational commitments), alongside such negative soft power counter-securitisation serves to desecuritise China and achieve a successful soft power engagement.

\section{Central-Eastern Europe: co-producing China's desecuritisation}

The 16+1 platform was established shortly before the BRI was first announced in order to assist with the implementation of the project in the CEE. This process started with the establishment of various direct train links between China and the region and the promise of Chinese investments in infrastructure projects. In comparison to the rest of EU, in years 2010-15 the CEE countries were in receipt of only about $5.78 \%$ of China's Foreign Direct Investments to the EU (Pepe 2017: p. 5) and the regional governments have hoped that the $16+1$ platform would help to attract such investments, redress the trade imbalance, and help the CEE companies enter the Chinese market. However, these expectations have still not materialised (Matura 2019). Moreover, instead of decreasing the 'China threat' perception in Western Europe, 16+1 became a source of increasing insecurity about China's intentions among the 'core' EU states. Yet, despite such reluctance towards the project and the limited tangible outcomes of the BRI investments in the region so far, the CEE governments have gladly embraced and echoed the upbeat and desecuritised narrative of Chinese engagement in the region. The question is therefore why these countries not only succumb to China's desecuritised portrayal of the BRI, but also actively co-produce it? To what degree is this a result of the deliberate China's soft power strategy in the region, as described in the previous section, and to what extent a result of the CEE states' own agency?

The main discursive tool of promoting the BRI is encapsulated in the language of desecuritisation as presented in the previous section. The CEE governments keenly 
adopt this exact language. The 2018 National Endowment for Democracy report reveals that high-profile politicians from Czech Republic (such as Milos Zeman and Bohuslav Sobotka), Hungary (Peter Szijjarto and Victor Orban) and Slovakia (Ivan Gasparovic and Robert Fico) have spoken overwhelmingly positively on China, and that this attitude coincided with the inception of the BRI (Karásková et al. 2018). The CEE politicians echo China's narratives by focusing on economic growth (while ignoring political consequences) that would come with investments and infrastructure projects, present the BRI projects as important for the CEE states' own modernisation, and emphasise 'cultural and scientific exchanges' which account for the 'humanism' of China-CEE relations (see Karásková et al. 2018; Kancelaria Prezydenta 2015; Radio Televizija Srbije 2017). As such language becomes 'a new common sense', it justifies the prioritisation of economy, cultural specificity and national sovereignty over common EU norms, such as those regarding human rights and democratic accountability. By doing so, the governments are actively co-producing China's soft power strategy of desecuritisation, allowing new normative and ideational influences.

But this desecuritisation is only possible, because it is conflated with the governments' own political aims. This is particularly visible in the case of the recent retreat from the EU's common approach to human rights in China. Some CEE governments, particularly the V4 states, have either blocked statements criticising China in EU meetings (Reuters 2017) or have on numerous occasions been vocal on the need to withdraw from 'criticising China over its human rights record'. In 2016 interview for the Chinese CCTV station, Czech president Milos Zeman reflected on his country's past approach to human rights in China, which had been one of the most critical in the EU (Fox and Godement 2009: p. 5), as a result of the former government's submissiveness 'to the pressure from the US and EU', and therefore erroneous. He then contrasted it with the transformed attitude of the new Czech administration: 'Now we are again an independent country, and we formulate a foreign policy which is based on our own national interest [and] we do not interfere with the internal affairs of any other country' (Zeman quoted in CCTV 2016). Likewise, in the 2016 'China-CEE Political Parties Dialogue' speech, Hungary's prime minister Victor Orban referred to China's engagement in the CEE as one of 'mutual respect' and 'mutual learning', which as he emphasised was quite unlike the 'Western way of thinking', which 'expects other regions of the world to embrace its international doctrines' because it thinks that it 'represents a superior ideal and culture'. In contrast, 'Hungarian people' believe that 'each house has its own customs, (...) each nation its own character, and that this is embodied in specific and unique political systems' and this is the spirit with which 'we look upon the Chinese political system' (Orban 2016). Similarly, in 2016 during the Parliamentary-established Day of Asia-Pacific, Polish foreign affairs vice-minister Jan Parys rejected the right of the Western states to criticise human rights issues in China: a declaration that was praised by the Chinese diplomats present at the meeting as an example of 'non-interference in the internal Chinese affairs' (Parys quoted in Tok FM 2016). The changing attitudes towards the Dalai Lama visits to the region, with countries withdrawing from meeting the Dalai Lama since the establishment of $16+1$ platform ${ }^{6}$ are also an extension of this new attitude towards human rights. The above cases highlight that while economic favours from China are certainly a motivation here,

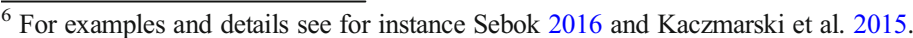


the countries are also keen to tie the desecuritised 'non-interference' approach to their own political aims of boosting domestic popularity by employing the language of nationalism and emancipation from Brussels.

This attitude is not reserved to the issues concerning EU's common policy towards human rights only; it also targets EU's common trade policy. In 2016, Hungary supported recognition of China as Market Economy, despite the EU's decision not to grant China that status. This was announced by the Hungarian trade minister Peter Szijjarto in the following words:

We think that China must be provided with the "Market Economy" status. (...) We understand European countries are eager to build economic and trade cooperation with China. (...) And this cooperation must be built on mutual respect and mutual trust. (Szijjarto quoted in $\mathrm{Wu} 2016$ )

Here, Hungary speaks out against common EU policy by directly employing the Chinese desecuritised language of the BRI promotion: that of 'mutual respect' and 'mutual trust'.

The adoption of the language of desecuritisation can result in a normative influence in the region, as it helps to replace the previously coveted values of liberal democracy and human rights with China-promoted norms of state sovereignty, economic pragmatism and even authoritarianism, as it forces the countries to revaluate the past ideological differences over the legacy of Communism and even to question their post-1989 choice of liberal democracy. Some governments claim that Chinese communism should not be criticised because it is 'of a different type'. In October 2016, during the previously mentioned Parliamentary-established Day of Asia-Pacific, Polish viceminister of foreign affairs, Jan Parys, announced China as a formally 'post-communist' country. According to him, this is because 'Chinese government has dealt with Communism more decisively than [we did] in Poland. Some communist leaders [in China] actually lost their lives' (Parys, quoted in Tok FM 2016). In order to justify its cosy relationship with the world's foremost communist state to its domestic audience, the Law and Justice government is quick to justify such announcements by turning its criticism to the Western states: Jan Parys bashed Western countries for the feeling of superiority of liberalism and free market economy, which Poland 'does not wish to partake in' (Parys, quoted in Tok FM 2016). Hungarian prime minister goes even further in its reappraisal of Chinese communism, questioning his country's own choice of liberal democracy. In the 2014 Victor Orban's speech at the XXV. Bálványos Free Summer University and Youth Camp in Hungary, he contrasted China's development model (alongside that of Russia and other authoritarian states), as an alternative choice for Hungary:

Today, the stars of international analyses are Singapore, China, India, Turkey, Russia. And I believe that our political community rightly anticipated this challenge. (...) We are searching for (and we are doing our best to find ways of parting with Western European dogmas, making ourselves independent from them) the form of organizing a community, that is capable of making us competitive in this great world-race. (...) In order to be able to do this (...), we needed to courageously state (...) that a democracy is not necessarily liberal. Just because 
something is not liberal, it still can be a democracy. Moreover, it could be and needed to be expressed, that probably societies founded upon the principle of the liberal way to organize a state will not be able to sustain their worldcompetitiveness in the following years, and more likely they will suffer a setback, unless they will be able to substantially reform themselves (Orban 2014).

These words come from a man who in 1980s led Hungarian opposition in their fight against the Communist regime. Clearly, as is the case with Poland, China is presented as an alternative to the Western political model, and the appraisal of Chinese version of communism is aimed at criticising the EU's Western member-states, therefore it adopts and relies on China's 'negative soft power' strategy for the domestic political ends of the regional governments.

The examples above illustrate that by adopting the China-promoted desecuritised language of the BRI as a 'new normal', some CEE countries participate actively in China's soft power strategy in the region at expense of the common EU norms. However, the key factor shaping such response is these governments' relations with Brussels and their attitudes to the EU, rather than an intrinsic attractiveness of Chinese norms. The turn towards China in the region coincided with the change in the CEE outlook towards the EU which emerged alongside the growing nationalist and populist forces in the region. Indeed, prior to the right-wing populist takeover in 2015 and 2013 respectively, Poland and Czech Republic were listed among 'assertive industrialist' countries in the 16+1 group, that is countries sceptical of China's investments (Fox and Godement 2009), with largely negative image of China and working towards a joint EU policy towards China (Song 2013). At the time, China did not succeed in spreading its 'charm offensive' and boosting its soft power strategies in the region, as the CEE populations continued to see China as the Communist 'Other' who did not follow liberal principles (Song 2013: p. 12). Yet, these countries governments' position changed dramatically with the ascent of populist politicians to power, who used their anti-EU and pro-China sentiment in their nationalistic rhetoric, which boosted China's soft power strategy in the region in new ways.

The transformation of China image in the region shows that the soft power strategy of desecuritisation is a co-produced process, as it can only effectively work when it falls on a fertile ground. In the case of CEE-China relations, this fertile ground is their shared anti-Brussel sentiments (or the 'community of shared disenchantment'), which then enables the adoption of desecuritisation not because desecuritisation is necessarily convincing - as we have seen it is full of contradiction - but mostly because it helps the local governments to assert themselves against Brussels. This is often achieved through the deemphasising of security matters in relations with China, and these countries' acceptance of the Chinese vision of BRI as non-threatening and depoliticised. China is seen as an ally in the growing anti-EU sentiments in the region (as seen in the case of the V4 countries) or as an alternative source of investments boosting the non-EU Balkan states' negotiating position with regard to the EU accession. 'China model', in this context, is not a Chinese export which is intended to subjugate and colonise, as some observers fear (Bryant and Chou 2016), but rather as an effective way for the regional nationalist governments to rely on the example of economic success of China to justify their own grab on power to their constituencies. In 
that sense, China becomes the tool in $16+1$ domestic squabbles as much $16+1$ is a tool in China's soft power policy.

\section{Responding to the desecuritisation/resecuritisation dynamic}

This article explored the role of the desecuritisation of the BRI as China's soft power strategy and the consequences of its deployment in the European periphery of CEE. The desecuritisation narratives use linguistic tools of emphasising economics over norms (i.e. 'pragmatic cooperation'), culture over politics (i.e. 'each nation has its own characteristic'), and sovereignty over supranational commitments (i.e. 'mutual respect' and 'non-interference in domestic political affairs') as the foundation of the BRI. Moreover, China spreads its concept of the BRI in a negative sense, by contrasting the lack of political conditionality of its economic investments abroad with the Washington (and Brussels) consensus model. The emphasis on economics, culture and sovereignty combined with negative language builds its soft power strategy of desecuritisation. By exploring the deployment, adoption and co-production of these narratives in CEE, this article pointed out the political consequences of China's soft power engagement in the region. Such co-production of China's soft power strategy of desecuritisation is possible because of China's careful engagement with regional dynamics and historical legacies, but also the particular interests of recipient states. In line with the words of Xi Jinping, who compared China's BRI expansion to 'peaches and plums, [which] do not speak, but they are so attractive that a path is formed below the trees' (Xi 2017), through its promises of economic investments and continuous promotion of its norms in the desecuritised language, China seeks to create a receptive environment for its growing economic and political presence.

It is important to mention that while this article focused on the case of the CEE region, there are similar tendencies of adopting China's desecuritised language and institutions all across peripheral Europe. For instance, the undersecretary of Economic Development of the 2018-elected right-wing Italian government has been vocally supportive of introducing some solutions of the 'China model' of governance in Italy, such as similar public security governance solutions and 'Chinese approach to migration management' (Geraci 2018). Greece has been one of the most vocal defenders of China in the EU; it refrained from signing a joint EU Human Right Declaration in 2017, the first such failure in the EU history. Therefore, the process is not necessarily limited to the $16+1$ platform, and should be viewed in a wider context of core-periphery relations in Europe. It is necessary to remember that while China's engagement might spur sub-regional fragmentation, the divisions in Europe are exploited rather than created by China.

The key theoretical finding of the research is that securitisation and desecuritisation should not be seen as positive or negative phenomena respectively. Both serve political purposes, and should be seen in that light, especially when they are portrayed as apolitical. Indeed, both seem to be contingent on one another. If the desecuritisation is so keenly adopted and co-produced solely for pragmatic reasons, how stable and successful can it be in a long-term? The recent debate in CSS indicates that desecuritisation is usually followed by resecuritisation (Floyd 2015: p. 137), or even that desecuritisation can never really happen, because the production of national 
identity perpetually requires 'insecurity and the designation of issues and actors as threats to the state' (Behnke 2006: p. 65). Bringing on desecuritisation through speech acts, which are intended to render an issue in non-security terms, is futile: if desecuritisation can be achieved at all, it is through non-speaking of the issue, that is, allowing for its importance and presence to wither away (Behnke 2006: p. 65). Clearly, Behnke's discussion of the futility of desecuritisation resonates well with the case of both Poland and Czech Republic, as they are quick to resecuritise China once the overriding security concerns, such as the need for the US military protection against 'closer threats', such as Russia, are perceived. ${ }^{7}$ This propensity to resecuritise also shows that the intended effects of desecuritisation are highly contingent on the stability of the co-production process. Institution-building seems necessary to 'fix' the desecuritisation; therefore, deepening of the current institution-building (such as 16+ 1) might go a long way in creating a truly advantageous perception of China in the region. Yet, in order to avoid the securitisation of such institutions, the EU as a whole must be more actively engaged in the process.

Acknowledgements The author wishes to thank Dragan Pavlićević and John Williams and the three anonymous reviewers for their most insightful comments on the drafts of this paper as well as the participants and audience of the EU-China panel on Central Eastern Europe in 2017 UACES conference in Krakow for their thoughtful remarks, which contributed to the paper's subsequent development.

Open Access This article is distributed under the terms of the Creative Commons Attribution 4.0 International License (http://creativecommons.org/licenses/by/4.0/), which permits unrestricted use, distribution, and reproduction in any medium, provided you give appropriate credit to the original author(s) and the source, provide a link to the Creative Commons license, and indicate if changes were made.

\section{References}

Aradau C (2004) Security and democratic scene: desecuritization and emancipation. J Int Relat Dev 7(4):388413

Bachulska A, Turcsányi R (2019) Behind the Huawei backlash in Poland and the Czech Republic, The Diplomat, 06 February 2019, Available online: https://thediplomat.com/2019/02/behind-the-huaweibacklash-in-poland-and-the-czech-republic/?fbclid=IwAR3 CacEd5iwOPK 12 cthr OElXNaCHmgRRHyfG7CfPoQCyUhuDk16PrvQAp0

Behnke A (2006) No way out: desecuritization, emancipation and the eternal return of the political. A reply to Aradau. J Int Relat Dev 9(1):62-69

Benner T, et al (2018) Authoritarian advance. Responding to China's growing political influence in Europe. Global Public Policy Institute Report, Available online: https://www.merics.org/sites/default/files/201802/GPPi MERICS Authoritarian Advance 2018 1.pdf. Accessed 30 Nov 2018

Biba S (2014) Desecuritization in China's behavior towards its transboundary rivers: the Mekong River, the Brahmaputra River, and the Irtysh and Ili Rivers. J Contemp China 23(85):21-43

Bourbeau P, Vuori J (2015) Security, resilience and desecuritization: multidirectional moves and dynamic. Crit Stud Secur 3(3):253-268

Breslin S (2011) The 'China model' and the global crisis: from Friedrich List to a Chinese mode of governance? Int Aff 87(6):1323-1343

\footnotetext{
${ }^{7}$ Poland has recently joined the international securitised response to Huawei by arresting the country's director of the company on the charges of espionage. Similarly, Ye Jianming, the director of CEFC, a privately-owned company, appointed the advisor to Czech president back in 2015, was arrested in 2018 on corruption charges in China, prompting a much more cautious approach to Chinese investments in the country (Bachulska and Turcsányi 2019).
} 
Bryant O, Chou M (2016) China's new Silk Road. Autocracy promotion in the new Asian order? Democratic Theory 3(2):114-124

Buzan B, Waever O, de Wilde J (1998) Security: a new framework of analysis. Lynne Reiner, Boulder

Callahan W (2015) Identity and security in China: the negative soft power of the China dream. Politics 35(34):216-229

Callahan W (2016) China's “Asian Dream”: the Belt and Road Initiative and the new regional order. Asian J Comp Polit 1(3):226-243

CCTV (2016) Czech President Milos Zeman on China-Czech ties, CCTV, 27 March 2016, Available online: http://english.cntv.cn/2016/03/27/VIDErzRMqU3S6DkYaTnLx8es160327.shtml

Cui S, Li J (2011) (De)securitising frontier security in China: beyond the positive and negative debate. Coop Confl 46(2):144-165

Danner L (2014) Securitization and de-securitization in the Diaoyu/Senkaku Islands territorial dispute. J Altern Perspect Soc Sci 6(2):219-247

EPSC (European Political Strategy Centre) (2016) Strategic note 16: engaging China at a time of transition, Available online: https://ec.europa.eu/epsc/file/strategic-note-16-engaging-china-time-transition_en . Accessed 24 Nov 2017

EUCC (European Chamber of Commerce) (2017) China manufacturing 2025. Putting industrial policy ahead of market forces, Available online: http://www.europeanchamber.com.cn/en/press-releases/2532 /european_chamber_report_cautions_against_the_negative_aspects_of_china_manufacturing_2025 . Accessed $\overline{1} 3$ Feb $20 \overline{1} 8$

Floyd R (2015) Just and unjust desecuritization. In: Balzacq T (ed) Contesting security: strategies and logics. Routledge, London

Fox J, Godement F (2009) A power audit of China-EU relations, European Council on Foreign Relations, Available online: https://www.ecfr.eu/page/-/ECFR12_-_A_POWER_AUDIT_OF_EU-CHINA_ RELATIONS.pdf

Gaspers J (2016) Germany wants Europe to help shape China's Belt and Road Initiative, The Diplomat, Published on 17 December 2016, Available at: https://thediplomat.com/2016/12/germany-wants-europeto-help-shape-chinas-belt-and-road-initiative/ . Accessed 20 Nov 2017

Geraci M (2018) China and the government of change, Beppegrillo, 11 June 2018, (in Italian), available at: http:/www.beppegrillo.it/la-cina-e-il-governo-del-cambiamento/

Godement F, et al (2011) The scramble for Europe, European Council on Foreign Relations report, Available online: http://www.ecfr.eu/page/-/ECFR37_Scramble_For_Europe_AW_v4.pdf. Accessed on 15 December 2018

Hala M (2018) Europe's new 'Eastern block', Politico, 13 April 2018, Available online: https://www.politico. eu/article/europes-new-eastern-bloc-china-economy-model-belt-road-initiative/. Accessed 30 Nov 2018

Hansen L (2012) Reconstructing desecuritisation: the normative-political in the Copenhagen school and directions for how to apply it. Rev Int Stud 38:525-546

Jeffery R (2009) Evaluating the 'China Threat': power transition theory, the successor-state image and the dangers of historical analogies. Aust J Int Aff 63(2):309-324

Jia, R (贾瑞霞) (2013) Win-win and multi-win - an analysis of China-CEE trade cooperation (双赢and多赢—— 解析中国一中东欧国家经贸合作), IREECAS. Available online: http://euroasia.cass.cn/news/730287.htm . Accessed 12 Dec 2017

Kaczmarski M, Jakóbowski J (2015) China-CEE: '16+1' as seen from Beijing (in Polish) The Centre for Eastern Studies 166 (Ośrodek Studiów Wschodnich), 14 April 2015, Available online: https://www.osw. waw.pl/sites/default/files/komentarze_166.pdf

Kaczmarski M, et al (2015) The China/Central and Eastern Europe summit: a new vision of cooperation, new instruments. The Centre for Eastern Studies (Ośrodek Studiów Wschodnich), 02 December 2015, Available online: https:/www.osw.waw.pl/en/publikacje/analyses/2015-12-02/china/central-and-easterneurope-summit-a-new-vision-cooperation-old

Kancelaria Prezydenta RP (2015) President Andrzej Duda's visit to China' (in Polish), 22 November 2015, Available online: http:/www.prezydent.pl/aktualnosci/wizyty-zagraniczne/art,33,w-niedziele-prezydentandrzej-duda-udaje-sie-z-wizyta-do-chin.html

Karásková I, et al (2018) Central Europe for sale: the politics of China's influence, National Endowment for Democracy Policy Paper 03, available online: https:/www.amo.cz/wp-content/uploads/2018/04/AMO_ central-europe-for-sale-the-politics-of-chinese-influence.pdf . Accessed 5 Dec 2018

Kavalski E (2013) The struggle for recognition of normative powers: normative power Europe and normative power China in the context. Coop Confl 48(2):247-267

Kerr D (2015) China's search for normative power and the possibilities of the Asian century. In: Gaskarth J (ed) China, India and the future of international society. Rowman \& Littlefield, Lanham, pp 105-128 
Kowalski B (2017) China's foreign policy towards Central and Eastern Europe: the '16+1' format in the South-South cooperation perspective. Cases of the Czech Republic and Hungary. Camb J Eurasian Stud 2017:1. https://doi.org/10.22261/7R65ZH

Kynge J, Peel M (2017) Brussel rattled as China reaches out to Eastern Europe, Financial Times, 27 November 2017, Available online: https://www.ft.com/content/16abbf2a-cf9b-11e7-9dbb-291a884dd8c6

Le Corre P (2016) What China's checkbook diplomacy means for Europe, Politico, 5 December 2016, Available online: http:/www.politico.eu/article/what-chinas-checkbook-diplomacy-means-for-europe/

Li K (2017) Speech by Chinese PM Li Keqiang at the 16+1 summit in Budapest, Delfi. The Lithuanian Tribune, 30 November 2017, Available online: https://en.delfi.lt/lithuania/foreign-affairs/speech-bychinese-pm-li-keqiang-at-the-161-summit-in-budapest.d?id=76507837

Liu Z (刘作奎) (2014) The role of China-CEE in the construction of Silk Road’s Economic Belt' (“中东欧在丝绸 之路经济带建设中的作用', 国际问题研究') Beijing: China Institute of International Studies (CIIS) (北京: 中国 国际问题研究院)

Liu Z (刘作奎) (2016) The direction of Polish Foreign Policy and Sino-Polish relations (“波兰的外交政策走向与 中波关系'), China and the World (中国与世界). 7:24-27

Liu Z (刘作奎), Chen S (陈思杨) (2017) Risks of and responses to the construction of One Belt One Road Euroasian Economic Corridor (一带一路’欧亚经济走廊建设面临的风险与应对'), Int Econ Rev (国际经济评论), 2017年第2期: 28-35

Liu Z (刘作奎), Golik K (卡塔里娜 高里克) (2016) The Origins and prospect of the Polish constitutional crisis in 2015 and its impact on Sino-Polish relations. (“2015 年波兰宪法危机根源, 前景及对中波系影响分析”), Eur Res (欧洲研究) 年2期: 106-120

Long J (龙静) (2014) China-CEE relations: development, challenges and countermeasures (“中国与中东欧国家关 系:发展, 挑战及对策'), Research on International Issues (国际问题研究)’, Beijing: China Institute of International Studies (CIIS) (北京: 中国国际问题研究院)

Long J (龙静) (2016) The opportunities and challenges of the One Belt One Road promotion in the CentralEastern European region (“一带一路”倡议在中东欧地区的机遇和挑战'), Eur Obs (欧洲观察) 年第6期: 1-20

Matura T (2019) The myth of Belt and Road in Central and Eastern Europe, Panda Paw Dragon Claw, 5 May 2019, Available online: https://pandapawdragonclaw.blog/2019/05/05/the-myth-of-the-belt-androad-in-central-and-eastern-europe

MOFA (Ministry of Foreign Affairs) (2015) Li Keqiang delivers speech at China-EU Business Summit, stressing to work together for new progress in China-EU relations, Ministry of Foreign Affairs of People's Republic of China, 30 June 2015, Available online: http:/www.fmprc.gov.cn/mfa_eng/topics_665678 /lkqcxdsqczgomldrhwbsfblsdfgjxzsfwbfwjjhzyfzzzzb/t1278051.shtml

NDRC (National Development and Reform Commission) (2015) Vision and actions on jointly building silk road economic belt and 21-st century maritime silk road, 28 March 2015, Available online: http://en.ndrc. gov.cn/newsrelease/201503/t20150330_669367.html

Nye J (1990) Soft power. Foreign Policy 80:153-171

Orban V (2014) Speech at the XXV Balvanyos Free Summer University and Youth Camp, Baile Tusnad (Tusnadfurdo), 26 July 2014, Available online: http://budapestbeacon.com/public-policy/full-text-ofviktor-orbans-speech-at-baile-tusnad-tusnadfurdo-of-26-july-2014/10592

Orban V (2016) Victor Orban's speech at the conference 'China-CEE Political Parties Dialogue', 6 October 2016, Available online: http://www.miniszterelnok.hu/viktor-orbans-speech-at-the-conference-china-ceepolitical-parties-dialogue/

Pavlićević D (2018) China Threat' and 'China Opportunity': politics of dreams and fears in China-Central and Eastern European relations. J Contemp China 27(113):688-702

Pepe JM (2017) China's inroads into Central, Eastern and South Eastern Europe: implications for Germany and the EU', DGAP-Analyse 3, Available online: https://www.ssoar. info/ssoar/bitstream/handle/document/56045/ssoar-2017-pepe-Chinas_Inroads_into_Central_Eastern. pdf. Accessed on 12 December 2017

Poggetti, Lukrezia. 2017. 'One China - One Europe? German Foreign Minister's Remarks Irk Beijing', The Diplomat, 9 September 2019, Available at: https://thediplomat.com/2017/09/one-china-one-europegerman-foreign-ministers-remarks-irk-beijing/ Accessed on 28 October 2018

$\mathrm{Pu} \mathrm{X}$ (2012) Socialisation as a two-way process: emerging powers and the diffusion of international norms. Chin J Int Polit 5:341-367

Radio Televizija Srbije (2017) Nedimović: Chinese market a huge chance for agriculture (Nedimović:Tržište Kine velika šansa za poljoprivredu), Radio Televizija Srbije, 17 January 2017, Available online: http://www.rts.rs/page/stories/sr/story/13/ekonomija/2595971/nedimovic-trziste-kine-velika-sansa-zapoljoprivredu.html 
Reuters (2017) Greece blocks EU statement on China human rights at UN, 18 June 2017, Available online: https:/uk.reuters.com/article/uk-eu-un-rights-idUKKBN1990G0

Sebok F (2016) Chinese media watch: Dalai Lama visits Central Europe, Institute of Asian Studies, 15 November 2016, Available online: http://www.asian.sk/en/chinese-media-watch-dalai-lama-visits-centraleurope/

Shi Z (2014) China-EU relations: crisis and opportunity, Carnegie-Tsinghua, 15 March 2014, Available online: http://carnegietsinghua.org/2016/03/15/china-eu-relations-crisis-and-opportunity-pub-63049

Song L (2013) From rediscovery to new cooperation: the relationship between China and Central and Eastern Europe. Eur China Obs 5:8-14

Tok FM. 2016. Poland de-communised China ('Polska zdekomunizowała Chiny), 06 October 2016, Available online: http://www.tokfm.pl/blogi/pgadzinowski/2016/10/polska_zdekomunizowala_chiny/1

Topgyal T (2016) The Tibetan self-immolations as counter-securitization: towards and inter-unit theory of securitization. Asian Secur 12(3):166-187

Van Ness P (1995) China as a third world state: foreign policy and official national identity. In: Dittmer L, Kim SS (eds) China's quest for national identity. Cornell University Press, New York, pp 194-214

Vangeli A (2018) Global China and symbolic power: the case of 16+1 cooperation. J Contemp China:1-14. https://doi.org/10.1080/10670564.2018.1458056

Vuori JA (2011) Religion bites: Falungong, securitization/desecuritization in the People's Republic of China. In: Balzacq T (ed) Contesting security: strategies and logics. Routledge, London, pp 186-211

Vuori JA (2018) Let's just say we'd like to avoid any great power entanglements: desecuritisation in post-Mao Chinese foreign policy towards major powers. Global Discourse 8(1):118-136

Walker C, Ludwig J (2017) Introduction. From 'Soft Power' to 'Sharp Power': rising authoritarian influence in the democratic world, in NED (National Endowment for Democracy), Sharp Power. Rising Authoritarian Influence. National Endowment for Democracy

Weaver O (1995) Securitization and desecuritization. In: Lipschutz R (ed) On security. Columbia University Press, New York

Wu G (2016) Hungary: EU should give China 'market economy' status, CCTV, 10 June 2016, Available online: http://english.cctv.com/2016/06/10/VIDEpCKf294TecatnMQbX9SI160610.shtml

Xi J (2015) Towards the community of common destiny and a new future for Asia, speech at the Boao Forum for Asia Annual Conference 2015, Boao, 28 March 2015, Available online: http://news.xinhuanet. com/english/2015-03/29/c 134106145.htm

Xi J (2016) Timeless friendship between Serbia and China (in Serbian), Srbija i Kina, Available online: http://srbijaikina.rs/si-dinping-vanvremensko-prijateljstvo-srbije-i-kine/ . Accessed 10 Oct 2018

Xi J (2017) Work together to build the silk road economic belt and the 21 st century maritime silk road, speech at Belt and Road Forum, Beijing, 14 May 2017, Available online: http://news.xinhuanet. com/english/2017-05/14/c_136282982.htm

Xinhua (2017) China voices support for European integration, Xinhua News, 8 March 2017, Available online: http://news.xinhuanet.com/english/2017-03/08/c_136112382.htm

Xu G (徐刚) (2013) Regional co-operation: new direction in China-CEE relations, (地方合作:中国- 东欧合作的新 方向), IREECAS, http://euroasia.cass.cn/news/746378.htm . Accessed 8 Dec 2017

Zhang L, Trigkas V (2015) Can China's new Silk Road end Greece's economic tragedy?, Carnegie Tsinghua, 11 May 2015, Available online: http://carnegietsinghua.org/2015/05/11/can-china-s-new-silk-road-endgreece-s-economic-tragedy-pub-60034

Zuvela M (2019) EU must embrace Balkans or lose them to Russia and China - Montenegro president, Reuters, 8 May 2019, Available online: https://uk.reuters.com/article/uk-eu-balkans-montenegro/eu-mustembrace-balkans-or-lose-them-to-russia-and-china-montenegro-president-idUKKCN1SE22Y?fbclid= IwAR31Rb1qDRf0X_dGY4BHC9FEIMxjzfj-eqmHBMiJQYFTN5ca6b-jmQuBoys

Publisher's note Springer Nature remains neutral with regard to jurisdictional claims in published maps and institutional affiliations. 